\title{
Fundamental Study of the Sintering of Iron Ores
}

\author{
By Koji Sanbongi* and Nobunao Nishida***
}

\section{Synopsis}

By using Larap magnetite ores and Goa hematite ores as raw materials, the relationship of the shapes of the temperature-time curves appearing in the sintering raw materials layer and the air-flow, the coke content and the moisture content was studied. The relationship of the heat movement in the unsintered raw materials layer and in the sinter layer and the air-flow also was investigated. From these experimental results it was ascertained that a distinct relation exists between the heat-front speed and the flamefront speed.

\section{Introduction}

In recent years, the blast furnace operation was markedly improved by the use of self-fluxing sinters, and this stimulated the construction of a number of sintering plants and the closer control of the sintering operation. Since the sintering process is so complex and unstable, few studies of its fundamental nature are reported in current publications ${ }^{1-8)}$. For this reason sintering experiments using Goa hematite ores and Larap magnetite ores were carried out with a small sintering pan, and studies were made of the influence of the air-flow, coke content and moisture content on the temperature-time curve at various levels of the sintering bed. (These will be called the sintering experiments.) Then, in order to ascertain the effects of heat transfer in the sintering processes, some experiments were made on the heat transfer characteristics in the unsintered layer and sinter layer. (These will be called the heat-flow experiments.) The moving speed of the "combustion and sintering zone" obtained in the sintering experiments and the heat-front speed measured in the heat-flow experiments were then correlated.

\section{Experimental Apparatus and Method}

\section{Experimental Apparatus}

A small sintering pan, having a capacity of 3 $\mathrm{kg}$ of iron ores, was used to carry out the experiments. The layout of apparatus is shown in Fig. 1. The sintering pan consisted of a steel tube, $105 \mathrm{~mm}$ in inside diameter and $250 \mathrm{~mm}$ in height, to which a base having a steel mesh grate was fitted. Holes were drilled through the side wall at a distance of 40,80 and $120 \mathrm{~mm}$ from the grate in order to place thermocouples for the measurement of the bed temperature. The sintering pan was covered with asbestos sheet for purposes of insulation. The Roots blower with a capacity of $0.56 \mathrm{~m}^{3} / \mathrm{mn}$ air-flow at $2,000 \mathrm{~mm} \mathrm{Aq}$ suction was

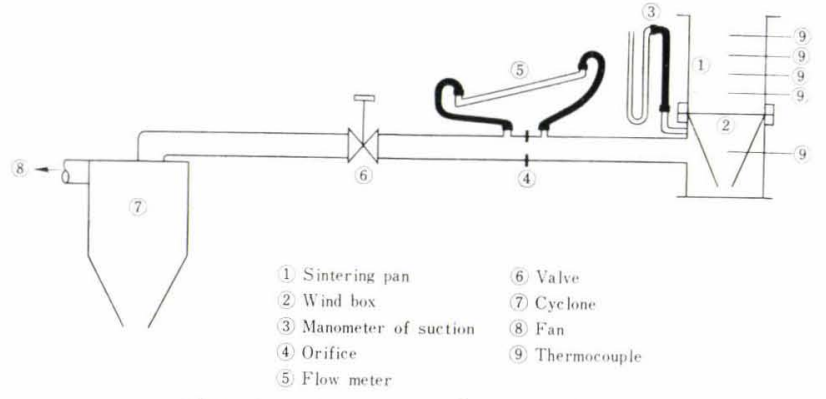

Fig. 1. Apparatus for experiments

used. In heat flow experiments, a hood was placed over the sintering pan and propane gas was burnt in this hood. The hood was made from a steel tube, $105 \mathrm{~mm}$ in inside diameter and $250 \mathrm{~mm}$ in height, and a base plate to which a number of steel pipes $10 \mathrm{~mm}$ in outside diameter were welded.

\section{Raw Materials}

Minus $5 \mathrm{~mm}$ Goa hematite ores and Larap magnetite ores were used for the experiments. Return fines were not added in order to investigate the respective ore characteristics. The coke used in the experiments was commercial products crushed down to $-1 \mathrm{~mm}$. Chemical analyses and size distribution of the iron ores are shown in Table 1.

Table 1. Chemical analyses and size distribution of iron ores

(a) Chemical analyses

\begin{tabular}{cccccccc}
\multirow{2}{*}{ Ores } & Comp. (\%) & Tot. $\mathrm{Fe}$ & $\mathrm{FeO}$ & $\mathrm{SiO}_{2}$ & $\mathrm{CaO}$ & $\mathrm{Al}_{2} \mathrm{O}_{3}$ & $\mathrm{~S}$ \\
\hline Goa & 56.61 & 3.04 & 3.66 & 0.84 & 6.04 & 0.06 \\
Larap & 56.34 & 27.56 & 9.34 & 1.96 & 2.06 & 2.21
\end{tabular}

(b) Size distribution

\begin{tabular}{l|rrrrrr}
\multicolumn{2}{l|}{ Size (mesh) } & $-4+9$ & $-9+16$ & $-16+32$ & $-32+100$ & -100 \\
\hline Goa & 63.6 & 22.1 & 7.4 & 5.2 & 1.7 \\
Larap & 44.2 & 28.3 & 15.9 & 9.1 & 1.5
\end{tabular}

\section{Experimental Procedure}

i. Sintering Experiments

A well-mixed raw feed was charged in the sintering pan to a fixed depth of $200 \mathrm{~mm}$, then the surface of the charge was covered with enough charcoal fines and sawdust for homogeneous ignition. In the course of charging the feed, a silica tube, $5 \mathrm{~mm}$

Lecture delivered before the 60th Grand Lecture Meeting of the Iron \& Steel Institute of Japan on Oct. 4 th, 1960 in Hokkaido. Japanese text was printed in "Tetsu-to-Hagané" (Journal, Iron \& Steel Institute, Japan) Vol. 46, No. 12, pp. 1527-1532 and Vol. 47, No. 5, pp. 687-692.

** Dr. Eng., Research Institute of Mineral Dressing and Metallurgy, Tohoku University.

*** Central Research Laboratory, Fuji Iron \& Steel Co., Ltd. 
in inside diameter and $100 \mathrm{~mm}$ in length, was inserted at each temperature-measuring point.

The charge was ignited using town gas under a limited air-flow for 30 seconds. Then the valve was opened and the air-flow adjusted to the desired flow rate, and the sintering was started. The valve opening was fixed at this point. During the experiment, temperature, suction and the pressure difference at the orifice were measured at every 15 seconds.

\section{ii. Heat-Flow Experiments}

In experiments using unsintered raw material layers, required amounts of moisture (for Goa hematite ores $7.0 \%$, for Larap magnetite ores $10.0 \%$ ) were added and mixed thoroughly, and then charged into the sintering pan to a depth of $200 \mathrm{~mm}$. In the present experiment several superposed sheets of $1 \mathrm{~mm}$ screen were used instead of bedding in order to hold the fines from escaping. After charging a silica tube was inserted at a distance of 40,80 and $120 \mathrm{~mm}$ from the grate.

In experiments using sinter layers, sintered products prepared by using optimum amounts of coke, moisture and air-flow were left in the sintering pan. (The Goa hematite ore was sintered by using $7.0 \%$ coke, $7.0 \%$ moisture and $0.4 \mathrm{~m}^{3} / \mathrm{mn}$ airflow, and the Larap magnetite ore was sintered by using $5.0 \%$ coke, $10.0 \%$ moisture and $0.4 \mathrm{~m}^{3} / \mathrm{mn}$ air-flow.) Silica tubes were inserted by boring holes through the sinter at each temperature-measuring point.

The aforementioned hood was then placed over the sintering pan, the valve was opened and the air-flow was adjusted to the desired rate. Propane gas was burnt for two minutes in the hood, the supply of the propane gas was stopped and temperature measurements were started at each point.

\section{Experimental Results and Discussions}

\section{Sintering Experiments}

In Fig. 2, temperature-time curves in the sintering bed of Larap magnetite ores are shown, in which $5.0 \%$ coke and $10.0 \%$ moisture were added and sintered with $0.4 \mathrm{~m}^{3} / \mathrm{mn}$ air-flow. When the Goa hematite ores were sintered, similar temperature-time curves were observed in the sintering

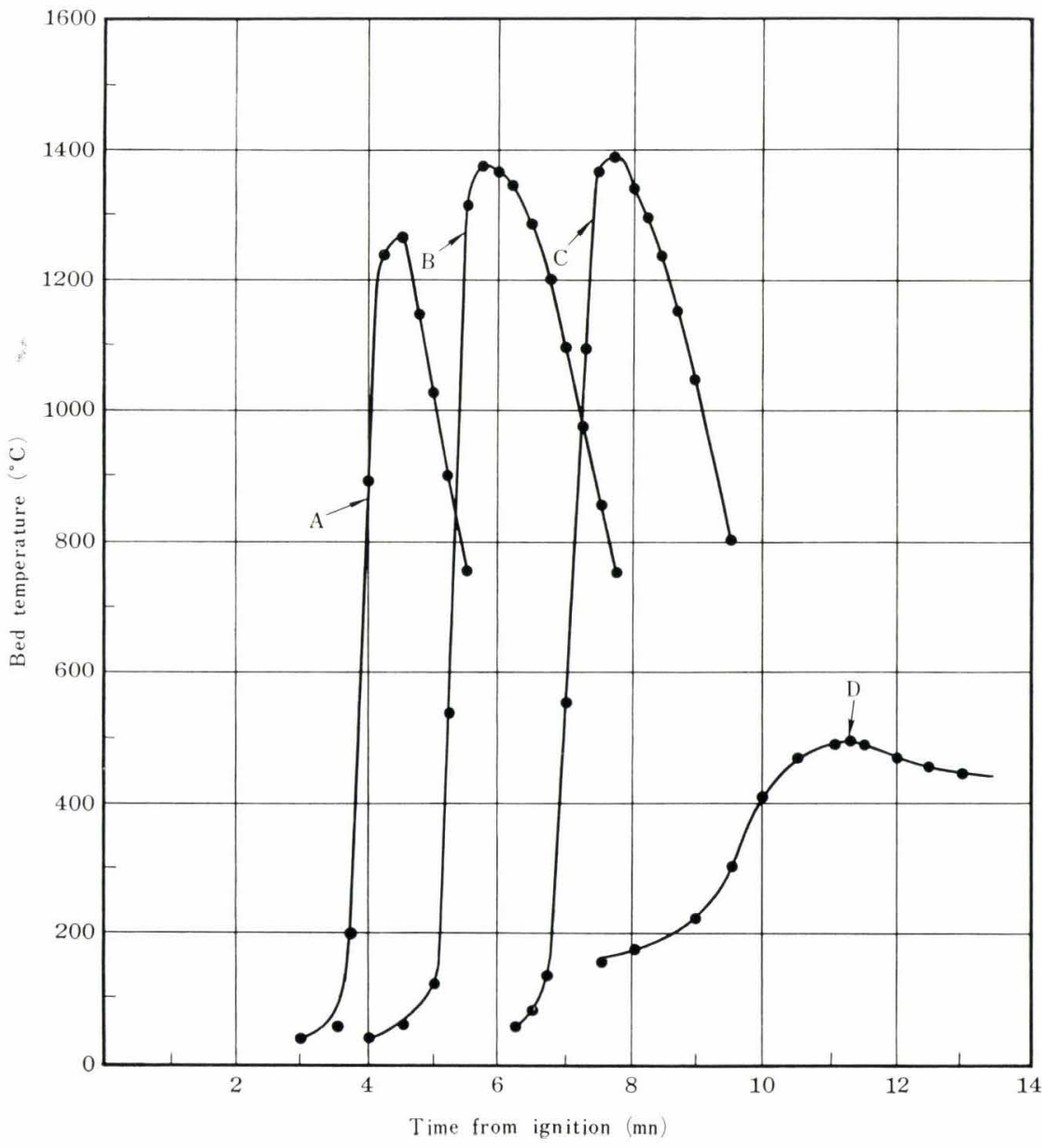

A: Distance from the grate $120 \mathrm{~mm}$

B: Distance from the grate $80 \mathrm{~mm}$ C: Distance from the grate $40 \mathrm{~mm}$ $\mathrm{D}$ : Waste gas temperature

Fig. 2. Temperature-time curve of Larap iron ores during sintering 
bed. It is readily seen in the figure that, as the measuring point came closer to the grate, the maximum temperature of the temperature-time curves gradually rose, whereas the bottom of these curves was stretched and the peak became broader. Since sintering of raw materials usually needed more than enough amount of coke in order to remove evaporable matter and to complete endothermic reactions, the excess heat generated in the sintering bed was transferred to the lower part of the bed simultaneously with the movement of the "combustion and sintering zone". Further, the heat was carried from the high temperature zone by the air-flow to the lower part of the bed. Thus, the heat accumulated in the bed and the temperature-time curves in the sintering bed took the shapes shown in Fig. 2.

For each sintering condition the temperaturetime curves mentioned above were obtained. From these curves the time required for the measuring point (for example, the point $80 \mathrm{~mm}$ from the grate) to reach a constant temperature (for instance $1,000^{\circ} \mathrm{C}$ ) was determined. The flame-front speed was calculated from the measured time and the distance between the measuring point and the surface of the charge. The results are shown in Table 2.

\section{i. Influence of the Air-Flow}

Because of many restrictions it was difficult to carry out the experiment under constant suction and constant air-flow, and the air-flow was adjusted to $0.2-0.6 \mathrm{~m}^{3} / \mathrm{mn}$ immediately after the ignition while the valve opening was fixed to that point.

Fig. 3 shows the temperature-time curves in the sintering bed using the Larap magnetite ore, which was sintered with $5.0 \%$ coke, $10.0 \%$ moisture and $0.2-0.6 \mathrm{~m}^{3} / \mathrm{mn}$ air-flow. Fig. 4 shows the temperature-time curves of the Goa hematite ore, that was sintered with $7.0 \%$ coke, $7.0 \%$ moisture and 0.2 $0.6 \mathrm{~m}^{3} / \mathrm{mn}$ air-flow.

It is clear from these figures that with both kinds of the ore, the increment of temperature increase for each temperature-time curve was greater for higher flow rate of the air. Therefore, if the ignition point of the coke was assumed to be $600^{\circ} \mathrm{C}$, the time required from this temperature to the maximum temperature of the temperaturetime curve would be 1 minute at $0.2 \mathrm{~m}^{3} / \mathrm{mn}$ air-flow and and 30 seconds at $0.6 \mathrm{~m}^{3} / \mathrm{mn}$. At the same time, the cooling rate of the red-hot sinter was greater and hence the peaks of the temperaturetime curves in Figs. 3 and 4, became sharper as the air-flow rate was increased. When the Larap ore was sintered at $0.2 \mathrm{~m}^{3} / \mathrm{mn}$ and the Goa hematite ore at $0.2 \mathrm{~m}^{3} / \mathrm{mn}$ and $0.3 \mathrm{~m}^{3} / \mathrm{mn}$, the peaks of the temperature-time curves became markedly broadened, and the flame-front speeds for the above condition became very low as shown in Table 2. Therefore, these phenomena were presumably observed when the flow rate of air was lower than that required for successful sintering, and also when the cooling rate of the red-hot sinter was slow. In the sintering of the Goa hematite ores at $0.3 \mathrm{~m} 3 / \mathrm{mn}$ air-flow the flame-front speed was again too slow, since the hematite ores required more heat and greater air-flow than the magnetite ores.

\section{ii. Influence of the Coke Content}

Temperature-time curves in the sintering bed using Larap magnetite ore which was sintered with $3.0-6.0 \%$ coke, $10.0 \%$ moisture and $0.4 \mathrm{~m}^{3} / \mathrm{mn}$ airflow, were shown in Fig. 5a. For the Larap magnetite ores the ideal temperature-time curve was

Table 2. Experimental results

(1) Sintering experiments

\begin{tabular}{|c|c|c|c|c|c|c|c|c|}
\hline \multirow[b]{2}{*}{ Ores } & \multirow[b]{2}{*}{$\begin{array}{l}\text { Coke } \\
\text { con- } \\
\text { tent } \\
(\%)\end{array}$} & \multirow{2}{*}{$\begin{array}{c}\text { Moisture } \\
\text { content } \\
(\%)\end{array}$} & \multirow[b]{2}{*}{$\begin{array}{c}\text { Air- } \\
\text { flow } \\
\left(\mathrm{m}^{3} / \mathrm{mn}\right)\end{array}$} & \multicolumn{4}{|c|}{ Flame-front speed $(\mathrm{mm} / \mathrm{mn})$} & \multirow{2}{*}{$\begin{array}{l}\text { Sinter- } \\
\text { ing time } \\
(\mathrm{mn})\end{array}$} \\
\hline & & & & $\begin{array}{c}120 \mathrm{~mm} \\
\text { from } \\
\text { grate }\end{array}$ & $\begin{array}{l}80 \mathrm{~mm} \\
\text { from } \\
\text { grate }\end{array}$ & $\begin{array}{c}40 \mathrm{~mm} \\
\text { from } \\
\text { grate }\end{array}$ & $\begin{array}{l}\text { Mean } \\
\text { value }\end{array}$ & \\
\hline \multirow{12}{*}{ \% } & 7.0 & 7.0 & 0.6 & 36.4 & 34.8 & 36.4 & 35.9 & 6.3 \\
\hline & " & " & 0.5 & 20.5 & 23.0 & 25.8 & 23.1 & 8.8 \\
\hline & ” & ” & 0.4 & 18.6 & 21.2 & 20.9 & 20.2 & 10.3 \\
\hline & " & " & 0.3 & 15.1 & 15.8 & 13.9 & 14.9 & 15.3 \\
\hline & " & ” & 0.2 & 8.7 & 10.2 & 10.8 & 9.9 & 30.0 \\
\hline & 8.0 & ” & 0.4 & 32.0 & 32.4 & 31.4 & 31.9 & 8.8 \\
\hline & 7.0 & " & " & 18.6 & 21.2 & 20.9 & 20.2 & 10.3 \\
\hline & 6.0 & ” & " & 16.0 & 18.5 & 18.4 & 17.6 & 16.5 \\
\hline & 5.0 & " & " & 12.3 & 15.4 & 16.0 & 14.6 & 19.0 \\
\hline & 7.0 & 9.0 & " & 21.1 & 22.6 & 23.5 & 22.4 & 10.0 \\
\hline & $"$ & 7.0 & " & 18.6 & 21.2 & 20.9 & 20.2 & 10.3 \\
\hline & " & 5.0 & " & 11.9 & 18.5 & 16.0 & 15.5 & 14.5 \\
\hline \multirow{12}{*}{ 䒕 } & 5.0 & 10.0 & 0.6 & 38.1 & 40.0 & 4.0 & 39.7 & 8.0 \\
\hline & $"$ & " & 0.5 & 22.9 & 27.3 & 30.0 & 26.7 & 9.0 \\
\hline & $"$ & " & 0.4 & 19.0 & 22.2 & 21.8 & 21.0 & 11.2 \\
\hline & $"$ & " & 0.3 & 18.2 & 19.2 & 18.8 & 18.7 & 15.5 \\
\hline & " & " & 0.2 & 9.5 & 9.0 & 8.7 & 9.1 & 30.0 \\
\hline & 6.0 & " & 0.4 & 29.1 & 26.7 & 26.3 & 27.4 & 11.2 \\
\hline & 5.0 & ” & $"$ & 19.0 & 22.2 & 21.8 & 21.0 & 11.2 \\
\hline & 4.0 & " & $"$ & 26.7 & 25.0 & 24.6 & 25.4 & 10.5 \\
\hline & 3.0 & " & $"$ & 16.0 & 12.6 & 13.0 & 13.9 & 16.0 \\
\hline & 5.0 & 9.0 & 0.3 & 20.0 & 20.5 & 22.5 & 21.0 & 11.5 \\
\hline & $"$ & 7.0 & " & 16.7 & 16.7 & 18.8 & 17.4 & 14.5 \\
\hline & " & 5.0 & " & 13.0 & 13.0 & 15.2 & 13.7 & 16.7 \\
\hline
\end{tabular}




\begin{tabular}{|c|c|c|c|c|c|c|c|c|c|c|c|c|c|}
\hline \multirow{2}{*}{ Ores } & \multirow{2}{*}{$\begin{array}{l}\text { Air-flow } \\
\mathrm{m}^{3} / \mathrm{mn}\end{array}$} & \multicolumn{4}{|c|}{$\begin{array}{l}\text { Heat-front speed in } \\
\text { unsintered layer } \\
(\mathrm{mm} / \mathrm{mn})\end{array}$} & \multicolumn{4}{|c|}{$\begin{array}{l}\text { Heat-front speed in } \\
\text { sinter layer } \\
(\mathrm{mm} / \mathrm{mn})\end{array}$} & \multicolumn{4}{|c|}{$\begin{array}{l}\text { Flame-front speed in } \\
\text { sintering experiments } \\
\qquad(\mathrm{mm} / \mathrm{mn})\end{array}$} \\
\hline & & $\begin{array}{l}120 \mathrm{~mm} \\
\text { from } \\
\text { grate }\end{array}$ & $\begin{array}{l}80 \mathrm{~mm} \\
\text { from } \\
\text { grate }\end{array}$ & $\begin{array}{l}40 \mathrm{~mm} \\
\text { from } \\
\text { grate }\end{array}$ & $\begin{array}{l}\text { Mean } \\
\text { value }\end{array}$ & $\begin{array}{l}120 \mathrm{~mm} \\
\text { from } \\
\text { grate }\end{array}$ & $\begin{array}{l}80 \mathrm{~mm} \\
\text { from } \\
\text { grate }\end{array}$ & $\begin{array}{l}40 \mathrm{~mm} \\
\text { from } \\
\text { grate }\end{array}$ & $\begin{array}{l}\text { Mean } \\
\text { value }\end{array}$ & $\begin{array}{l}120 \mathrm{~mm} \\
\text { from } \\
\text { grate }\end{array}$ & $\begin{array}{l}80 \mathrm{~mm} \\
\text { from } \\
\text { grate }\end{array}$ & $\begin{array}{l}40 \mathrm{~mm} \\
\text { from } \\
\text { grate }\end{array}$ & $\begin{array}{l}\text { Mean } \\
\text { value }\end{array}$ \\
\hline \multirow{5}{*}{ Goa } & 0.6 & 13.3 & 16.0 & 16.4 & 15.2 & 29.1 & 32.0 & 29.1 & 30.1 & 32.0 & 30.0 & 31.0 & 31.0 \\
\hline & 0.5 & 10.3 & 12.3 & 12.3 & 11.6 & 24.6 & 26.7 & 26.7 & 26.0 & 16.8 & 20.0 & 20.2 & 20.2 \\
\hline & 0.4 & 9.7 & 11.2 & 12.1 & 11.0 & 21.3 & 25.3 & 23.7 & 23.4 & 16.8 & 20.0 & 19.4 & 19.4 \\
\hline & 0.3 & 8.6 & 7.9 & 7.5 & 8.0 & 17.8 & 20.9 & 20.6 & 19.7 & 13.9 & 13.7 & 13.6 & 13.6 \\
\hline & 0.2 & 7.0 & 6.6 & 6.4 & 6.7 & 15.2 & 19.2 & 17.8 & 17.4 & 8.0 & 9.4 & 9.6 & 9.6 \\
\hline \multirow{5}{*}{ Larap } & 0.6 & 16.8 & 17.1 & 16.0 & 16.7 & 24.6 & 26.7 & 29.1 & 26.8 & 35.6 & 36.9 & 36.0 & 36.0 \\
\hline & 0.5 & 13.9 & 13.7 & 13.3 & 13.7 & 22.9 & 25.3 & 27.8 & 25.3 & 21.3 & 25.3 & 24.4 & 24.4 \\
\hline & 0.4 & 10.0 & 10.9 & 10.3 & 10.4 & 20.0 & 21.8 & 20.6 & 20.8 & 17.8 & 20.9 & 19.8 & 19.8 \\
\hline & 0.3 & 9.0 & 10.2 & 9.1 & 9.5 & 16.8 & 16.0 & 16.4 & 16.1 & 17.8 & 17.8 & 17.8 & 17.8 \\
\hline & 0.2 & 7.3 & 6.9 & 6.7 & 6.9 & 12.8 & 13.7 & 13.0 & 13.2 & 8.9 & 7.8 & 8.3 & 8.3 \\
\hline
\end{tabular}

observed at $5.0 \%$ coke, whereas at $6.0 \%$ coke the flame-front speed was somewhat higher but cooling rate became slower, and thus the peaks of the temperature-time curves were broadened. At $4.0 \%$ coke, the flame-front speed was almost the same as that at $5.0 \%$ coke, but the maximum temperature of the temperature-time curves was lower. If it is assumed that it is necessary to reach $1,300^{\circ} \mathrm{C}$ to get a sinter with sufficient physical strength, then, the maximum temperature of $1,300^{\circ} \mathrm{C}$ is reached after the measuring point No. 3 , only $1 / 5$ of the sinter bed is thought to be acceptable in this case. At $3.0 \%$ coke, the maximum temperature of temperature-time curves was lower yet, and the measuring point No. 3 reached a point just above $1,000^{\circ} \mathrm{C}$. The product in the last case was very brittle. In sintering the Larap magnetite ores, therefore, the maximum temperature of the sintering zone was higher as the coke content was increased, but at $4-6 \%$ coke the flame-front speed was nearly the same.

Fig. 5b shows the temperature-time curves in the sintering bed using the Goa hematite ore, which was sintered with $5.0-8.0 \%$ coke, $7.0 \%$ moisture and $0.4 \mathrm{~m}^{3} / \mathrm{mn}$ air-flow. In sintering the Goa hematite ore, the temperature-time curves at $7.0 \%$ coke and $8.0 \%$ coke were very similar to each other and showed an ideal shape. On the other hand, the temperature-time curves at $6.0 \%$ and $5.0 \%$ coke showed the tendency that the maximum temperatures became lower, the flame-front speeds became slower and the heat became insufficient. In sintering the Goa hematite ores, therefore, the flamefront speed was increased and the maximum temperature of the sintering zone became higher as the coke content was increased.

Thus, the influence of the coke content on the temperature-time curves of the sintering zone was apparently much different between sintering of hematite ores and that of magnetite ores. This was presumed to be due not only to the difference in the sulphur content and in the heat requirement, but to the difference in the oxidation of $\mathrm{Fe}_{3} \mathrm{O}_{4}$ and in the beginning time of $\mathrm{Fe}_{2} \mathrm{O}_{3}$ reduction.

iii. Influence of the Moisture Content

Fig. 6a shows the temperature-time curves in the sintering bed using the Larap magnetite ore, which was sintered with $5.0 \%$ coke, $5.0-9.0 \%$ moisture and $0.3 \mathrm{~m}^{3} / \mathrm{mn}$ air-flow. It is readily seen from this figure that the flame-front speed was increased and the peaks of the temperature-time curves became sharper as the moisture content was increased. Fig. $6 \mathrm{~b}$ shows the temperature-time curves using the Goa hematite ore, which was sintered with $7.0 \%$ coke, $5.0-9.0 \%$ moisture and $0.4 \mathrm{~m}^{3} / \mathrm{mn}$ air-flow. Again in this case, like the Larap magnetite ore, the flame-front speed was enhanced with increasing moisture content. When compared the temperaturetime curves of moisture content of $9.0 \%$ (Fig. 6b, $1 \mathrm{~A}, 1 \mathrm{~B}, 1 \mathrm{C})$ with those of $7.0 \%(2 \mathrm{~A}, 2 \mathrm{~B}, 2 \mathrm{C})$, the flame-front speed at $9.0 \%$ moisture was apparently faster than that at $7.0 \%$ moisture at the measuring points No. 1 and No. 2. At the measuring point No. 3, however, the both flame-front speeds were almost the same. This was probably due to the condensation of the moisture at the lower part of the bed, and to the variation of the physical nature of the unsintered layer being affected by the movement of the flame-front. In the sintering of the Larap magnetite ores, the above phenomena were not observed since the moisture content was adjusted to $5.0-9.0 \%$, which was just about the same 

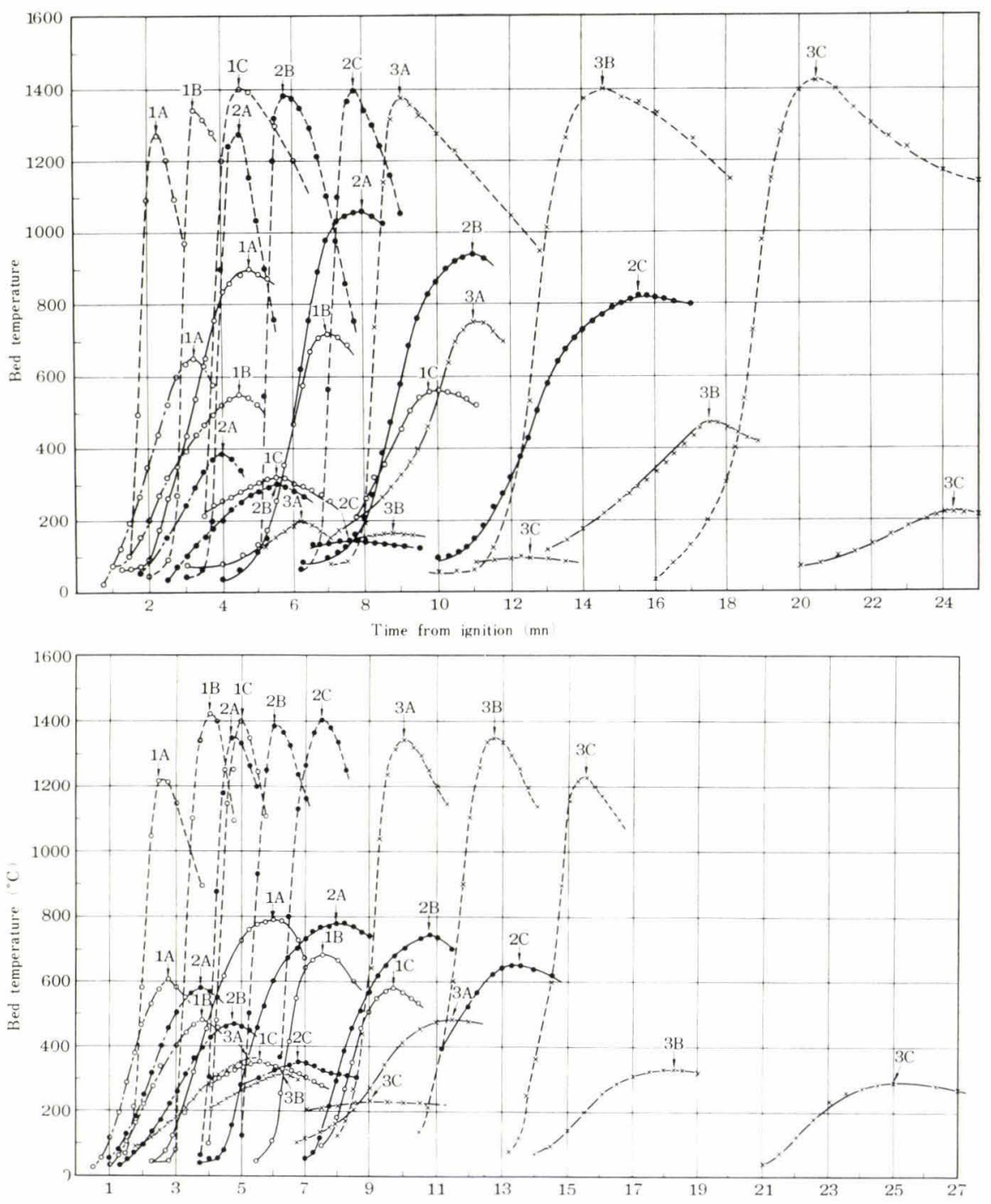

Time from ignition $\mathrm{mn}$

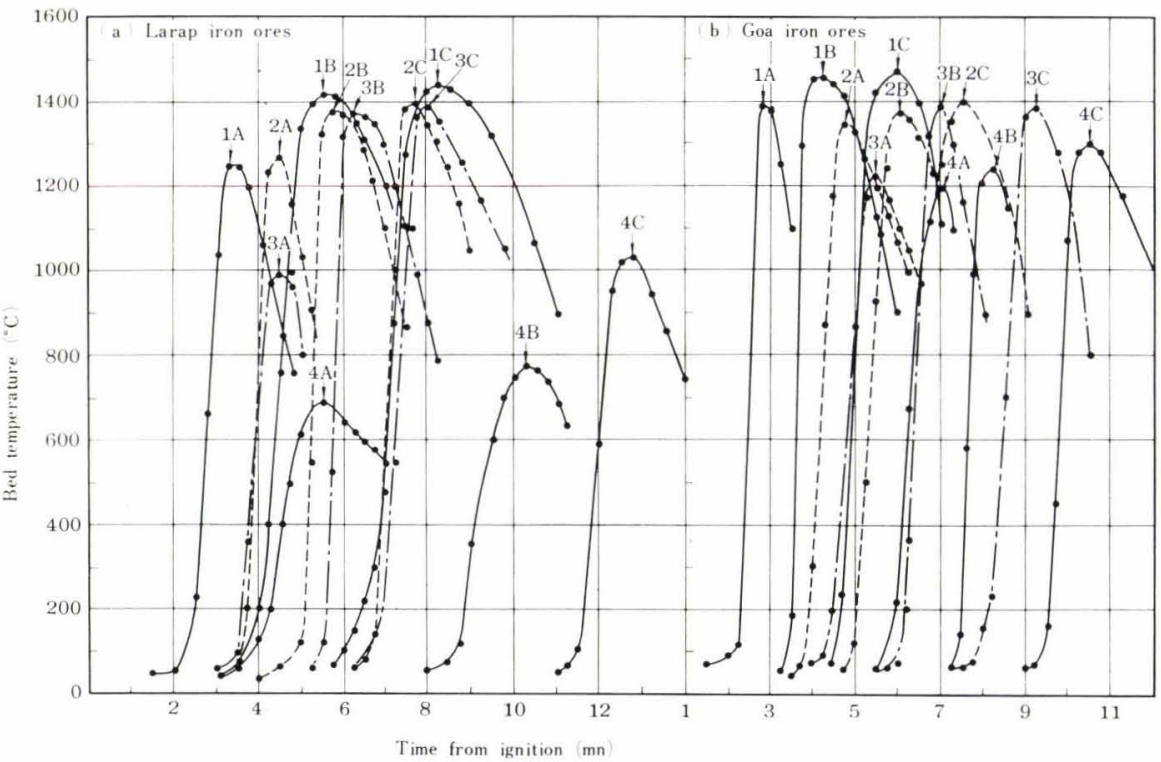

- Sintering experiment

Heat-flow experiment in unsintere layer

Heat-flow experiment in sinter laye

1. Air-flow $0.6 \mathrm{~m}^{3} / \mathrm{mn}$

2. Air-flow $0.4 \mathrm{~m}^{3} / \mathrm{mn}$

$3 \times$ Air-flow $0.2 \mathrm{~m}^{3} / \mathrm{mn}$

A: Distance from the grate $120 \mathrm{~mm}$

B: Distance from the grate $80 \mathrm{~mm}$

C: Distance from the grate $40 \mathrm{~mm}$

Fig. 3. Relation between bed temperature distribution of Larap iron ores and air-flow during various sinterings

\footnotetext{
-.---- Sintering experiment

Heat-flow experiment in unsintered layer

Heat-flow experiment in sinter laye

1. Air-flow $0.6 \mathrm{~m}^{3} / \mathrm{mn}$

2. Air flow $0.4 \mathrm{~m}^{3} / \mathrm{mn}$

$3 \times$ Air-flow $0.2 \mathrm{~m}^{3} / \mathrm{mn}$

A : Distance from the grate $120 \mathrm{~mm}$

B : Distance from the grate $80 \mathrm{~mm}$

C: Distance from the grate $40 \mathrm{~mm}$
}

Fig. 4. Relation between bed temperature distribution of Goa iron ores and air-flow during various sinterings

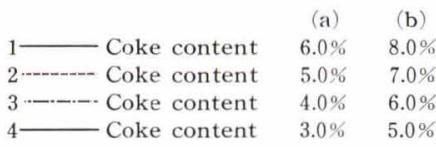

A: Distance from the grate $120 \mathrm{~mm}$

B: Distance from the grate $80 \mathrm{~mm}$

C: Distance from the grate $40 \mathrm{~mm}$

Fig. 5. Relation between bed temperature distribution of Larap and Goa iron ores and coke content during sintering 


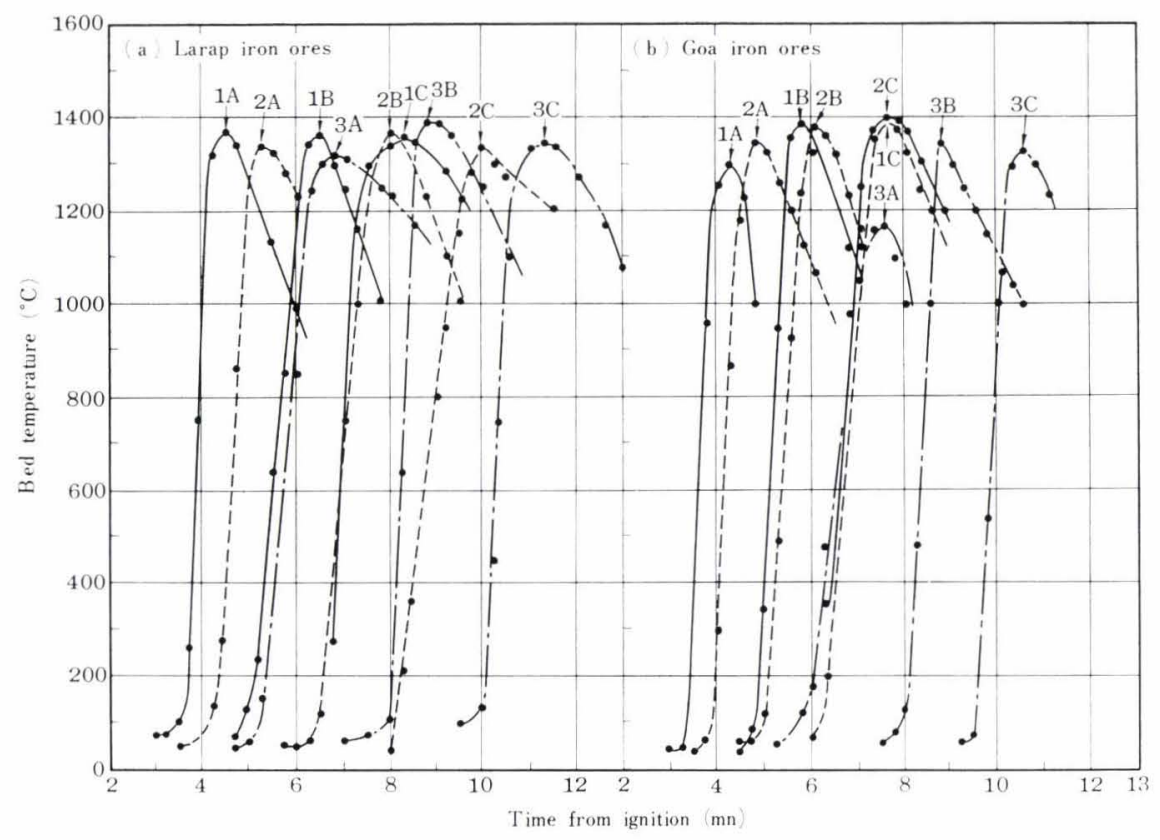

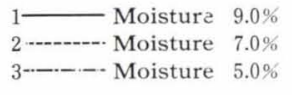

A: Distance from the grate $120 \mathrm{~mm}$

B : Distance from the grate $80 \mathrm{~mm}$

C: Distance from the grate $40 \mathrm{~mm}$ as for the Goa hematite ores, but was lower than the optimum value. If $11.0-12.0 \%$ moisture were added, the flame-front speeds would have been suppressed by the condensation of moisture etc.

\section{Heat-Flow Experiments}

Typical results with the Goa hematite ores are partly shown in Fig. 4 and with Larap magnetite ores in Fig. 3. Table 2 shows the heat-front speeds and flame-front speeds, calculated from the time required for the temperature-time curve (Figs. 3 and 4) to reach a maximum.

\section{i. Heat Movement in the Unsintered Layer}

Fig. 4 shows temperature-time curves obtained with the Goa hematite ore together with $7 \%$ moisture when the heat was applied to the surface layer and was moved downward by the air-flow of 0.2 $0.6 \mathrm{~m}^{3} / \mathrm{mn}$. It is readily seen from this figure that the peaks of the temperature-time curves in the heat-flow experiment became sharper as the airflow rate was increased, but in the temperaturetime curves observed in the sintering experiment the peaks tended to be broader, and then the heatfront speed was slower than the flame-front speed. These phenomena were probably due to much lowering of the permeability of the charge by the loss of the moisture in the layer just before and after the heat-front, thus, the voids needed for the air-flow were closed and the moisture condensed in face of the heat-front.

In order to investigate the reason for the above phenomena the next experiments were carried out. The air heated by propane gas for two minutes was passed through the charge, which contained
$10.2 \%$ moisture, at the rate of $0.4 \mathrm{~m}^{3} / \mathrm{mn}$, and after five minutes the valve closed and the moisture content of each part of the charge was measured. The temperature at the distance of $120 \mathrm{~mm}$ from the grate was then $287^{\circ} \mathrm{C}$. The moisture content of the point $70 \mathrm{~mm}$ above the grate was $12.5 \%$, but above this point the moisture decreased markedly; at 85 $\mathrm{mm}$ from the grate it was $2.8 \%$ and at $100 \mathrm{~mm}$ it was $0 \%$.

The relation between the air-flow, suction and moisture content was tested by changing the valve opening for various additions of moisture to the Goa hematite charge. It was shown from the experimental results that on both sides of the moisture $10.0 \%$, the increase in suction resulted in a marked decrease in the air-flow, in other words, in a decrease in the permeability. From these experimental results it is readily explained that the heatfront speed in the unsintered layer was very much slower than the flame-front speed due to the lowering of the permeability of the raw materials layer before and after the heat-front.

Fig. 3 shows temperature-time curves obtained with the Larap magnetite ore together with $10.0 \%$ moisture when the heat was moved downward by the air-flow of $0.2-0.6 \mathrm{~m}^{3} / \mathrm{mn}$. Here in this experiment, the same reasoning as applied to the Goa hematite ores may be made: heat-front speeds were slower than the flame-front speeds, but the same relation was obtained as to the air-flow for both speeds, and the peaks of the temperature-time curves became sharper as the air-flow was increased.

Comparison of Fig. 3 with Fig. 4 shows that the maximum temperatures of the temperature-time curves of the heat-flow experiments using the Larap 
magnetite ores were higher than those using Goa hematite ores. This was probably due mainly to the combustion of $2 \%$ sulphur contained in the Larap magnetite ore.

\section{ii. Heat-Flow Experiments in the Sintered Layers}

The experimental results where the heat was moved in the sinter products, made by sintering the Goa hematite ores with $7.0 \%$ coke, $7.0 \%$ moisture and $0.4 \mathrm{~m}^{3} / \mathrm{mn}$ air-flow, are shown in Fig. 4 as a function of the air-flow.

This sintered layer had very high permeability and then the heat-front speeds in these experiments were faster than those in the unsintered layer. At $0.6 \mathrm{~m}^{3} / \mathrm{mn}$ air-flow the heat-front speeds in the present experiment were nearly equal to the flamefront speed observed in the sintering experiment, whereas for other values of the air-flow the heatfront speeds were faster than the flame-front speeds. This was thought to be due to a difference in the increment of the temperature increase caused by the combination of coke at $0.6 \mathrm{~m}^{3} / \mathrm{mn}$ and at other rates of air-flow.

The experimental results where the heat was moved in the sinter products, made by sintering the Larap magnetite ores with $5.0 \%$ coke, $10.0 \%$ moisture and $0.4 \mathrm{~m}^{3} / \mathrm{mn}$ air-flow, are shown in Fig. 3 as a function of the air-flow.

As in the case of the Goa hematite ore, the heatfront speeds in the sintered layer were faster than the flame-front speeds in the sintering experiments for $0.2-0.5 \mathrm{~m}^{3} / \mathrm{mn}$ air-flow. It was worthy of note that the heat front-speed at $0.2 \mathrm{~m}^{3} / \mathrm{mn}$ air-flow was very much slower than the speeds at the other airflow, and the maximum temperature of each temperature-time curve became very low as the air-flow rate was decreased. This was due to the fact that the Larap magnetite sinter had a larger specific heat than the Goa hematite sinter and thus a majority of heat was stored in the upper layer, and little heat was moved by the air towards the lower parts of the bed.

iii. Relationship between the Heat Movement and the Sintering Speed in the Sintering Process

A few minutes after ignition, the charge presumably was divided into five zones, namely the cold sinter zone, the red-hot sinter zone, the combustion and sintering zone, the preheat zone, and the cold raw materials zone. Therefore, the "red-hot sinter zone" was located over the "combustion and sintering zone", and the former was cooled by the air drawn through the zone, thus the "cold sinter zone" was increased. The air, thus preheated, was sent to the "combustion and sintering zone". The "preheat zone" and the "cold raw materials zone" were located below the "combustion and sintering zone". The heat generated in the "combustion and sintering zone" was completely absorbed in the "preheat zone" and the "cold raw materials zone". This heat would escape as waste gas only when the "combustion and sintering zone" and "red-hot sinter zone" approached the grate" . When the size of the ore in the feed was small, then the surface area of the feed was large and thus the heat movement in the feed would be very much affected by the air-flow passing through this material.

If it is assumed that the sintering undergoes the above five zones, the heat-flow experiments in the unsintered layer correspond to the heat movement in the "preheat zone" and the "cold raw materials zone", and the heat-flow experiments in the sintered layer correspond to the heat movement in the "cold sinter zone" and "red-hot sinter zone".

The relationship between the distance of each measuring point from the grate and the time required for each point to reach maximum temperature, as read from the temperature-time curves of the Larap magnetite (Fig. 3) and the Goa hematite (Fig. 4), showed straight lines for each air-flow condition on both ores; and the slope of each line was observed to correspond with the heat-front speed and the flame-front speed as shown in Table 2(b). It is evident from Table 2 that the heatfront speeds in the unsintered raw materials layers and in the sinter layer are considerably different. This would be due to the fact that the specific surface area in the "cold raw materials zone" and the "preheat zone" was smaller than that in the "redhot sinter zone" and the "cold sinter zone". Therefore, a longer time was needed to move the same amount of heat at the same rate of air-flow in the unsintered raw materials layer, thus more heats were consumed in order to evaporate the moisture contained.

It is seen from the experimental results as shown in Table 2, that at each air-flow the heat-front speed in the unsintered raw materials layer was about one half of that in the sinter layer. Since the Larap magnetite ore contained about $2.0 \%$ sulphur (which was burnt during the sintering), the heat-front speeds in the unsintered raw materials layer were somewhat accelerated.

If the sintering process of the Goa hematite ore with $0.6 \mathrm{~m}^{3} / \mathrm{mn}$ air-flow was considered, the heat contained in the "cold sinter zone" and the "red-hot sinter zone" moved to the lower part of the charge at the speed of $30.1 \mathrm{~mm} / \mathrm{mn}$, whereas the heat-front speed in the unsintered raw materials layer was $15.2 \mathrm{~mm} / \mathrm{mn}$. Only a part of the heat which moved from the upper sinter layer, therefore, was transferred to the lower part of the layer and a greater 
part of the heat remained in the "combustion and sintering zone", and thus the latter heat added to the combustion heat of the coke and the temperature of the "combustion and sintering zone". The flame-front speeds in the sintering experiments were nearly equal to the heat-front speeds in the sinter layer. From these facts it was assumed that, when the heat-front speeds in the sinter layer were nearly equal to the flame-front speeds in the sintering experiments and also when the differences among the heat-front speeds in the unsintered layer, the heat-front speed in the sinter layer and the flame-front speed in the sintering experiments were smaller, then the temperature in the charge was raised more suddenly and the peaks of the temperature-time curves became sharper.

On the other hand the flame-front speed in the sintering experiments using Larap magnetite ores was $36.0 \mathrm{~mm} / \mathrm{mn}$ and the heat-front speed in the sinter layer was $26.8 \mathrm{~mm} / \mathrm{mn}$, thus the difference in the above two speeds was fairly large and the peak of the temperature-time curve was broadened as compared to that using Goa hematite ores. This tendency became more conspicuous as the air-flow was lowered.

The heat-front speeds in the sinter layer and the difference in the two speeds became large as the air-flow rate was decreased. This difference became larger as more heat moved from the red-hot sinter zone, accumulated in the "combustion and sintering zone", and thus the latter broadened and the cooling of the red-hot sinter became slower if the air-flow was kept constant. Then the peaks of the temperature-time curve became broadened and the maximum temperature of the temperature-time curves dropped slowly.

In the heat-flow experiments the heat was carried by air. In actual sintering processes the heat movement from the "red-hot sinter zone" to the "combustion and sintering zone" presumably is due to the air-flow and the heat movement from the "combustion and sintering zone" to the unsintered layer mainly depends on the combustion of waste gas. The composition of the combustion waste gas is dependent on the choice of raw materials, coke content and air-flow. Since the heat content of combustion waste gas is reported to be higher than the $\operatorname{air}^{10)}$, the heat-front speed in the unsintered layer could be higher for actual processes than for these experimental results. In the unsintered materials layer the permeability is low and hence the air-flow passing the layer is low; therefore, in actual sintering processes not only the heat movement by air but also the direct transfer from one ore particle to another should be taken into consideration.

\section{Conclusion}

Using Larap magnetite ores and Goa hematite ores as raw materials, an investigation was made on the relationships between the shape of the temperature-time curve which appeared in the sintering raw materials layer, and the air-flow, the coke content and the moisture content respectively. Also a study was made of the relationship between the heat movement in the unsintered raw materials layer and in the sinter layer, and the air-flow. From these experimental results it was determined that a definite relationship existed between the heat-front speed and the sintering speed. The following conclusions were obtained from the experimental results.

(1) The air-flow rate influenced markedly the combustion speed of coke, the advancing speed of the "combustion and sintering zone" and the cooling speed of the "red-hot sinter", and thus gave some effects on the shapes of the temperature-time curves observed in the charge. The flame-front speed was markedly low at $0.2 \mathrm{~m}^{3} / \mathrm{mn}$ air-flow with the Larap magnetite ores and at 0.2 and $0.3 \mathrm{~m}^{3} / \mathrm{mn}$ with the Goa hematite ores, and gave much influence to the shapes and the maximum temperatures of the temperature-time curves.

(2) The coke content influenced the flame-front speeds and the maximum temperatures of the temperature-time curves, but this effect was widely different by the choice of the iron ores used. Normally excess coke broadened the "combustion and sintering zone" and decreased the cooling rate of the "red-hot sinter", and thus influenced the shape of the temperature-time curve. However, it scarcely effected the maximum temperature. On the other hand, insufficient coke content markedly lowered the maximum temperature.

(3) Increase and decrease of the moisture content showed the same tendency as the increase and decrease of the air-flow, but scarcely influenced the maximum temperature of the temperature-time curve.

(4) In unsintered raw materials layers, because of the condensation and evaporation of the added moisture, the heat-front speed in this layer became slower, and the difference between the heat-front speed in this layer and the flame-front speed in the sintering experiments became large as the airflow rate was increased. In actual sintering processes, the heat movement in the unsintered raw materials layer was mainly due to the combustion waste gas, therefore, it was presumed that the actual speed was faster than the experimental results.

(5) The heat-front speed in the sintered layer was faster than the heat-front speed in the un- 
sintered raw materials layer, because of the high permeability of the sinter products. When the airflow was kept below $0.6 \mathrm{~m}^{3} / \mathrm{mn}$, the heat-front speed in this layer was faster than the flame-front speed in the sintering experiments.

(6) As the heat-front speed in the sinter layer came closer to the flame-front speed in the sintering experiments, and as the differences among the heat-front speed in the unsintered raw materials layer, the heat-front speed in the sinter layer and the flame-front speed in the sintering experiments became smaller, the increment of temperatureincrease in the temperature-time curves became suddenly greater and the peaks of the temperaturetime curves became sharper.

\section{REFERENCES}

1) B. Hessle: Jernkont. Ann. 129 (1945), 333.

2) R. D. Buringame, G. Bitshianes and T. L. Joseph : J. Metals 8, (1956), 853.

3) E. M. McBriar, W. Johnson, K. W. Andrews and W. Davies: J. Iron \& Steel Inst. (U. K.) 177 (1954) 316.

4) E. W. Voice and R. Wild: J. Iron \& Steel Inst. (U. K. $183(1956) 404$.

5) E. W. Voice and R. Wild: J. Metals 10 (1958) 104.

6) E. W. Voice and R. Wild: Proc. Blast Furnace 16 (1957) 123.

7) E. W. Voice and R. Wild: Iron \& Coal Trades Rev. 175 (1957) 847.

8) W. Davies and D. W. Mitchell: International Mineral Dressing Congress, Stockholm (1957).

9) H. B. Wendeborn: J. Iron \& Steel Inst. (U. K.) 175 (1953) 28.

10) J. Michard: Iron \& Coal Trades Rev. 175 (1957) 1477. 